\title{
Geology of the Juína Diamondiferous Province
}

\author{
Teixeira, N.A. ${ }^{1}$, Gaspar J.C. ${ }^{2}$, Waissel O. ${ }^{1}$, Almeida, A. J. ${ }^{3}$, Belther, J.A. ${ }^{4}$, Gobbo, L. ${ }^{5}$
}

1. Rio Tinto Desenvolvimentos Minerais Ltda. SCS Ed. Morro Vermelho, 10 andar, Brasília, DF, Brazil.

2. Instituto de Geociências, Universidade de Brasília, 70910-900 Brasília, DF, Brazil.

3. Golden Star - End.: Sia Trecho 3 - lote 990 Bloco "D" sala 203 71200-030 Brasilia, DF, Brazil.

4. Phelps Dodge do Brasil Mineração Ltda, R. da Glória, 344, Gr. 602/604, Glória 20241-180,Rio de Janeiro, RJ, Brazil

5. NOMOS Laboratório, R. Pereira Passos, 237, Pq. Boa Vista, 25085-300 Duque de Caxias, RJ, Brazil.

The Cretaceous Juina kimberlite province is located at the northern border of the Parecis Palaeozoic basin, which is underlain by the Mesoproterozoic sialic Rio Negro-Juruena mobile belt. The province was discovered by the BRGM/De Beers joint venture through stream gravel regional survey. The Parecis basin (1,250 km long x $400 \mathrm{~km}$ wide), host of the majority of Juína kimberlites, has $6000 \mathrm{~m}$ of siliciclastic sediment and underwent intense tectonic activity and basaltic volcanism in the Jurassic. A U/Pb zircon radiometric age of $92-95 \mathrm{Ma}$ from a volcaniclastic kimberlite breccia (Heaman et al. this volume) is consistent with palinologic studies in the craters sediments which indicate an age of 93,5 Ma, that correspons to the top of the Cenomonian.

The Juina province is roughly in accordance with the mega-lineament AZ 125, which controls a large number of ultramafic alkaline rocks in Brazil (Gonzaga and Tompkins, 1991). This lineament represents a major lithospheric suture, probably crossing lithospheric domains of different composition, thermal regime, and metasomatic history. In detail, the Juina province is placed in a northeast tectonic system ( $20 \mathrm{~km}$ wide $\mathrm{x} 100 \mathrm{~km}$ long) that is a small graben filled by Palaeozoic and Cretaceous sediments. More than ninety percent of the kimberlite bodies are found in this tectonic compartment. The other ten percent are inserted directly into the sialic substract that is the Rio Negro-Juruena Mobile Belt. The majority of the kimberlite structures are intruded in the Permo-Carboniferous Casa Branca Formation which was deposited in a glacio-marine and lacustrine environment. The Parecis Formation (Upper Cretaceous) covers the top of the Juina kimberlite craters. The twenty three kimberlite structures seem to be the result of a series of explosions (Strombolian Type) with distinct energy producing a complex pile of pyroclastic falls and surge (lapillistone and crystal tuff kimberlite), interbeded with resedimented volcaniclastic kimberlite. The morphology of the explosive structures is not typical of kimberlite bodies due to the absence of a classic diatreme and the presence of large craters.

There are two distinct types of explosive kimberlite structures (maars). One type of structure is settled in Palaeozoic sediments and the other in the granitic basement (Teixeira et al., this volume). Three compartments are generally observed in the maars: Facies 1: corresponds to the upper unit and is composed of metachronous volcanogenic sandstone layers which thickness varies from few centimeters to $60 \mathrm{~m}$. Normally, there is no kimberlitic contribution to such sandstones. Facies 2: occupies an intermediate position in the volcanic structure, being characterised by a complex intercalation of resedimented kimberlite ash and lapilli-rich sandstone with lapilli kimberlite and kimberlitic olivine crystal tuff. These are deposited as air-fall and surge inside the crater itself. Its thickness varies between 10 and $70 \mathrm{~m}$. The resedimented volcaniclastic kimberlite levels present rhythimic, graded, and cross-bedding generated by gravity flow of different densities. The deposition must have occurred right after the end of activities at a time when the tuff ring and crater walls still existed. The pyroclastic kimberlite accumulations (lapilli and tuffs) frequently present graded bedding, have a reddish brown colour (subaerial oxidation), which frequently include fragments with pelletal texture. At the microscope, the pelletal fragments are composed of euhedric 
olivine crystals mantled by extremely fine material of brown colour. Some brown microfragments resemble palagonitised shards. The kimberlite bodies that have intruded the granite-gneiss basement do no present air-fall or base surge deposits in its intermediate unit. This level is substituted by lagoon accumulation with local turbidite deposits. The lagoon deposits are rich in amorphous carbonaceous material and pollen of the Angiosperm and Gymnosperm type and some spores dated preliminarily as 93,5 Ma (top of the Cenomonian). Facies 3: this is the intrusive portion of the structures and occurs at their bottom and walls. This Facies is composed mainly by a greenish pelletal-textured volcaniclastic kimberlite and autolithic and heterolitic volcaniclastic kimberlite breccia. These rocks present two serpentinised olivine populations (euhedric and rounded), carbonate, phlogopite, spinels, chromium diopside, megacryst suite minerals ( $\mathrm{Cr}$-Ti pyrope and ilmenite), and calcic pyrope and spinels xenocrysts. The breccia displays textural features identical to diatreme facies of typical kimberlites and is characterised by a large amount of xenoliths (shales, gabbros, granites, mantle peridotites). The vent facies rocks show fluidisation textures. Some craters present a main explosive event followed by intermitent lower-energy pulses, probably similar to a strombolian activity.

The geological evolution of the Rio Negro-Juruena Mobile Belt (lateral versus vertical accretion) and the Juína's kimberlite geotectonic setting (on craton versus off craton) are still controversial. So far no bona fide allochtonous accretion terranes have been found in this belt. On the other hand, the $\mathrm{Sm} / \mathrm{Nd}$ model ages in rocks from the belt always point to a mantelic differentiation around 1,8 $\mathrm{Ga}$, without any evidence of relict Archean crust (Tassinari, 1989; Bizzi and Pimentel, oral communication). The Juína kimberlites would have then penetrated a lithosphere deeply modified during the Mesoproterozoic. Eclogite and garnet granular lherzolite are the most abundant mantle xenolith in the kimberlites (Teixeira, under preparation). Most of the xenocrysts are garnet (lherzolitic G-9 and eclogitic low-sodium G-3) and spinel. The mantelic spinels show $\mathrm{Cr}_{2} \mathrm{O}_{3}$ contents up to $58 \mathrm{wt} . \%$ and moderate $\mathrm{MgO}$ contents (<10 wt. \%). The chemical signature of both garnet and spinel indicates a non-depleted lithosphere. It is possible to state that the lithosphere beneath the Rio Negro-Juruena Mobile Belt was fundamentally constituted by lherzolite and eclogite reset at the Mesoproterozoic and that, consequently, the Juína diamonds should not be associated with a depleted harzburgite Archean keel. This is also supported by $\mathrm{Sm} / \mathrm{Nd}$ data (Bizi and Pimentel, oral communication; Pimentel and Teixeira, under preparation).

The Juína diamonds occur in alluvium (São Luiz, Mutum, Porcão, Juininha, Rio Vermelho, and Samambaia rivers) and in some kimberlite bodies (Haralyi, 1991; Gonzaga and Tompkins, 1991). Almost all alluvial diamondiferous rivers, with a total production of more than 8 million carats, drain the Chapadão plateau, a thin unit made up of immature sediments $(90 \mathrm{Ma} ; \mathrm{U} / \mathrm{Pb}$ dating in mantelic zircons) with numerous granite and gneiss pebbles. These sediments are rich in kimbelite indicator minerals and represent wet mud flows deposits, down slope in active faults in the sialic basement, in arid climate. The Juína diamonds are predominantly industrial and very seldom are found in stones up to $480 \mathrm{ct}$. Most diamonds present dodecahedral to irregular shapes but octahedral, and aggregate are also found. Predominant colours are brown and light brown, although, white, milky, yellow, and pink also occur. The majority of the stones contain many inclusions and present etched, frosted, and striated surfaces as well as dissolution lamellae, roll relief, trigons, and pits.

Cathodoluminescent images were obtained from 100 stones from alluvium (São Luís and Duas Barras rivers) and from kimberlite intrusions. It is possible to identify primary features such as octahedral growth faces repeatedly truncated by resorption since the beginning of the diamond 
formation. All studied diamonds are crystal fragments displaying a high degree of resorption, etching, brecciation, and annealing at various stages (Gaspar et al., this volume). Such features explain the low price of the stones. Another observed feature is the presence of slip planes or dislocations indicating that these diamonds would have undergone plastic deformation during mantle residence while the breccia textures indicate stages of brittle deformation. Cathodoluminescent features of diamonds from alluvium and intrusion are essentially similar. Compared to the diamonds from cratonic areas the Juína diamonds present a much more complex growth history.

The Juína diamonds are known to have been formed in the Transition Zone or even in the Lower Mantle due to the mineralogical assemblage included in diamonds from the São Luiz river (majorite, periclase-wüstite solid solution, $\mathrm{Ni}, \mathrm{Cr}$, and $\mathrm{Al}$ in the oxide phases, and $\mathrm{SIC}$ ) (Widing et al., 1991; Harte and Harris, 1994; Harte et al., 1994; Harris et al., 1996). Besides Juína, also Monastery and Jagersfontein have evidence of kimberlitic asthenospheric protomelts of depths superior to $670 \mathrm{~km}$ (Haggerty, 1991). According to Haggerty (1991) all these bodies would have intruded craton edges; regions that are privileged locus for plume induced magmatic activity. We are analysing the possibility that the Juína kimberlites and diamonds had a global evolution linked to the Nazca plate journey to the Transition Zone.

Note: kimberlite has been used here to name the Juína rocks but the detailed study of groundmass minerals is still under way and, consequently, a conclusive nomenclature has not yet been established.

We thank RTDM for allowing this publication.

\section{Acknowledgements}

\section{REFERENCES}

Gonzaga, G.M., Tompkins, L.A., 1991. Geologia do Diamante: Principais Depósitos Minerais do Brasil, v. IV, Parte A, p.53-116.

Haggerty, S.E., 1991, Emplacement and implications of ultra-deep xenoliths and diamonds from the transition zone: Fifth International Kimberlite Conference, Extended Abstracts, CPRM, p. 157159.

Haralyi, N.L.E., 1991, Os diamantes de Juína, Mato Grosso: Principais Depósitos Minerais do Brasil, v. IV, Parte A, p. 155-160.

Harte, B. and Harris, J.W., 1994, Lower mantle mineral associations preserved in diamonds: Mineral Mag., v. A 58, p. 384-385

Harte, B., Hutchison, M.T. and Harris, J.W., 1994, Trace element characteristics of the lower mantle: an ion probe study of inclusions in diamonds from São Luiz, Brazil: Mineral Mag., v. A 58, p. 386-387.

Harris, J., Hutchison, M.T., Hursthouse, M., Light, M. and Harte, B., 1997, A new tetragonal silicate mineral occurring as inclusions in lower-mantle diamonds: Nature, v. 387, p. 486-488.

Tassinari, C.C.G., Teixeira, W., Junior, O.S., 1989, Archean Early Proterozoic Crustal Evolution of Amazonian Craton, Brazil: 28 $8^{\text {th }}$ International Geological Congress, Washington, D.C. USA, Abstracts, v. 3, p. 221.

Wilding, M.C., Hart, M.C., Harrys, J.W., 1991, Evidence for a deep origin for São Luiz Diamonds: Fifth International Kimberlite Conference, Extended Abstracts, CPRM, p. 456-458. 